\title{
The Management Of Anemia In Patients With HCV Treated With
} DAA

University "Ovidius" of Constanta, Faculty of Medicine

\begin{abstract}
Hepatitis $\mathrm{C}$ virus (HCV) infection affects approximately 180 million people worldwide, which accounts for roughly $2 \%-3 \%$ of the world's population. Complications arising from chronic $\mathrm{HCV}$ infection include the development of cirrhosis, end stage liver disease, and hepatocellular carcinoma (HCV).

Objective: The study analyses management of anemia with patients in administrating DAA treatment (Telaprevir for 12 weeks).

Material and method: We conducted a study on 24 patients who have concluded the DAA administration period, being now in the period of finalization of standard therapy.

Results: Anemia was the most common adverse reaction, 17 patients ( $70.8 \%$ ),mild anemia 5 patients (20.8\%),medium anemia 8 patients( $47 \%$ ),severe anemia 4 patients $(24 \%)$. Hemoglobin levels were recorded during therapy, mild $\mathrm{Hgb}$

(10.0-10.9g/dl),medium Hgb (9.99-9.9 g/dl), severe

$\mathrm{Hgb}(7.0-8.9 \mathrm{~g} / \mathrm{dl})$, and analyzed the management of anemia in these patients.

In the first 3 months of therapy ( DAA+PegINF and RBV ), doses of DAA not changed.

Any doses of RBV were not modified in patients with mild anemia, in patients with moderate anemia patients received lower doses of $\mathrm{RBV}$, while those with severe anemia patients received lower doses of RBV and red blood cells mass.

Conclusions: Anemia was common adverse reaction in
\end{abstract}

Angelica Nela Stavar

Faculty of Medicine, Constanta, Romania

1st University Alee, Camp B

email : angel.stavar@yahoo.com patients with DAA compared with previous results, only PegINF end RBV. Lowering the dose of RBV in the first 3 months, when patients received DAA did not affect SVR.

Keywords: direct-acting antiviral agents, Hepatitis C virus, sustained virologic response.

\section{Introduction:}

According to Singh G, at al (2013) Chronic hepatitis $\mathrm{C}$ virus (HCV) infection affects 180 million people worldwide, and the growing complication of hepatocellular carcinoma has been contributing to increased number of deaths. The sustained virologic response (SVR) for patients with HCV genotype 1 infection was approximately $40 \%$ with this previous standard of therapy of pegylated interferon (PEG) and ribavirin (RBV) [1]. Sustained virological response is defined as absence of viremia [the presence of a virus in the blood] 24 weeks after cessation of all antiviral medication. Although SVR has long-term durability, data on the relationship with improved survival to support its use as a surrogate end point of antiviral therapy is scarce [2].

In 2011, protease inhibitors, telaprevir and boceprevir, were brought out of phase III clinical trials into the real life setting and have since played a revolutionary role in the treatment for hepatitis $\mathrm{C}$ virus genotype 1 infection [3]. Higher SVR rates of $68-79 \%$ were achieved in hepatitis $\mathrm{C}$ treatment naive patients who received combination therapy of 
boceprevir or telaprevir along with RBV and PEG during these trials $[4,5]$.

Treatment with available direct-acting antiviral (DAA) drugs has increased sustained virologic response (SVR) rates in genotype 1 infection and shortened duration of therapy in many patients, but these agents have a low barrier to resistance. Initial monoterapy studies of these agents showed prompt suppression of virus and rapid emergence of resistance, requiring that they be administered along with a interferon alfa and ribavirin to prevent resistance, 12 weeks and 24 weeks after stopping DAA treatment [6-7].

\section{Objective}

The study analyses management of anemia with patients in administrating DAA treatment (Telaprevir for 12 weeks).

\section{Material and method}

We conducted a study on 24 patients who have concluded the DAA administration period, being now in the period of finalization of standard therapy.

The patients have been evaluated at screening visit in clinical (physical examinations) and paraclinical terms: laboratory (HLG, biochemical analysis, urine collection, virus $\mathrm{C}$ genotype) liver biopsy or fibroscan, echography, electrocardiogram.

Study assessments at each study visit $(1,2,4$, 6, 8, 12 weeks) may include: blood (HLG, ALT, AST, $\mathrm{BT}, \mathrm{BD}$, lipid profile, uric acid, electrolytes) and urine collection for testing, electrocardiogram (ECG) assessments, physical examinations, pregnancy test for female.

\section{Results}

We enrolled 24 patients known to have chronic hepatitis C, 16 male and 8 female, age between 32 64 years old, (median age 48 years), 6 patients null responder and 18 partial responder, with F3-F4 fibrosis by METAVIR score (Table 1).

Table 1. Baseline caracteristics

\begin{tabular}{|l|l|l|}
\hline Gender & $\mathrm{M} / \mathrm{F}$ & $16 / 8$ \\
\hline Age & 32-64 years & Median 48 years \\
\hline $\begin{array}{l}\text { Resopons } \\
\text { to previous } \\
\text { treatment with } \\
\begin{array}{l}\text { PegIFN and } \\
\text { RBV }\end{array}\end{array}$ & $\begin{array}{l}\text { null responder/ } \\
\text { partial responder }\end{array}$ & $6 / 18$ \\
\hline $\begin{array}{l}\text { Fibrosis by } \\
\text { METAVIR score }\end{array}$ & F3/F4 & \\
\hline
\end{tabular}

The duration of the therapy association with DAA (Telaprevir $2250 \mathrm{mg} /$ day, $750 \mathrm{mg}$ at every 8 hours after eating) at the standard treatment was 3 months with remarkable virulogical results meaning that there was a high rate of undetectable viremia at W12, after the utilization of the triple therapy (83.3\%), only two patients had detectable viremia at $\mathrm{W} 12$.

Anemia was the most common adverse reaction, 17 patients $(70.8 \%)$, mild anemia 5 patients $(20.8 \%)$, medium anemia 8 patients (47\%), severe anemia 4 patients (24\%). Hemoglobin levels were recorded during therapy, mild Hgb (10.0-10.9g/dl), medium Hgb (9.99-9.9 $\mathrm{g} / \mathrm{dl})$, severe Hgb (6.5-8.9 $\mathrm{g} / \mathrm{dl})$, and analyzed the management of anemia in these patients. 


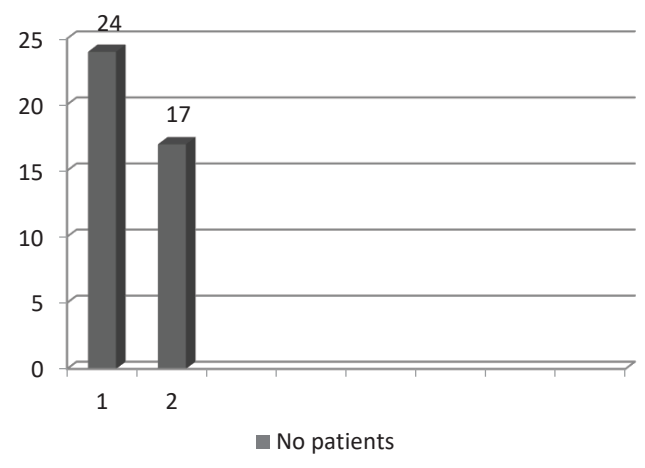

Figure 1

Table 2. Adverse reactions

\begin{tabular}{|l|l|l|l|}
\hline $\begin{array}{l}\text { Adverse } \\
\text { reaction }\end{array}$ & Mild & Medium & Severe \\
\hline anemia & $\begin{array}{l}5 \text { patients } \\
(20.8 \%)\end{array}$ & $\begin{array}{l}8 \text { patients } \\
(47 \%)\end{array}$ & $\begin{array}{l}4 \text { patients } \\
(24 \%)\end{array}$ \\
\hline
\end{tabular}

We considered the following parameters:

Table 3

\begin{tabular}{|l|l|c|l|l|}
\hline Parameter & $\begin{array}{l}\text { Adverse } \\
\text { reaction }\end{array}$ & Mild & Medium & Severe \\
\hline $\mathrm{Hgb}$ & anemia & $\mathrm{b} 9 \mathrm{dP}-10.9$ & $\begin{array}{l}9.99-9.9 \\
\mathrm{~g} / \mathrm{dl}\end{array}$ & $\begin{array}{l}6.5-8.9 \\
\mathrm{~g} / \mathrm{dl}\end{array}$ \\
\hline
\end{tabular}

In severe anemia we have reduced the dose of ribavirin at $600 \mathrm{mg} / \mathrm{day}$, and we have not stopped taking Telaprevir. In severe anemia, 2 were life threatening $(\mathrm{Hb}=6.5 \mathrm{~g} / \mathrm{dl})$ required transfusion of packed red blood cells.

\section{Discussion}

Boceprevir or telaprevir plus ribavirin (RBV) and pegylated interferon- $\alpha(\operatorname{pegIFN}-\alpha)$ is the new standard-of-care therapy for patients who are chronically infected with genotype 1 hepatitis $\mathrm{C}$ virus (HCV). The addition of these protease inhibitors to the $\mathrm{RBV} / \mathrm{pegIFN}-\alpha$ combination regimen has significantly improved rates of sustained virologic response (SVR); however, the incidence of anemia has also increased significantly. Anemia can interfere with patients' quality of life, work productivity, and treatment adherence. Severe anemia can cause morbidity and even mortality. For the management of anemia during triple combination therapy, RBV dose reduction is recommended as an initial course of action. In the first 3 months of therapy ( DAA + PegINF and RBV), doses of DAA not changed.

Any doses of RBV were not modified in patients with mild anemia, in patients with moderate anemia patients received lower doses of RBV, while those with severe anemia patients received lower doses of RBV and red blood cells mass.

\section{Conclusions}

Chronic HCV infection, addressed as a public health problem, both global and national, predominantly affecting middle-age people, active both socially and professionally, generate involvement from specialists in the sense of a permanent optimization of therapy to maintain equilibrium in the balance of cost / efficiency. The triple therapy, with DAA added to the standard therapy proves its utility despite the various adverse reactions recorded, high rates of sustained viral reaction justifying its utilization.[8].

Anemia was common adverse reaction in patients with DAA compared with previous results, only PegINF end RBV. Lowering the dose of RBV in the first 3 months, when patients received DAA did not affect SVR. 


\section{References}

1. Singh, G., Issa, D., Sedki, E., Hanouneh, I., Lopez, R., Zein, N. \& Alkhouri, N. (2013). Anemia in Patients with Chronic Hepatitis C Infection during Triple Therapy with Telaprevir or Boceprevir - A Controlled Study. J Antivir Antiretrovir 5: 173-177. doi: 10.4172/ jaa. 1000084

2. American Medical Association (AMA). (2012). Sustained virological response linked with improved survival for HCV patients.ScienceDaily. Retrieved 2017 from www.sciencedaily.com/ releases/2012/12/121226080336.htm

3. Alkhouri, N., \& Zein, N.N. (2012). Protease inhibitors: silver bullets for chronic hepatitis $\mathrm{C}$ infection? Cleve Clin J Med, 79(3), 213-222. doi: 10.3949/ccjm.79a.11082

4. Jacobson, I.M., McHutchison, J.G., Dusheiko, G., Di Bisceglie, A.M., Reddy, K.R., Bzowej, N.H., Marcellin, P., Muir, A.J., Ferenci, P., Flisiak, R., George, J., Rizzetto, M., Shouval, D., Sola, R., Terg, R.A., Yoshida, E.M., Adda, N., Bengtsson, L., Sankoh, A.J., Kieffer, T.L., George, S., Kauffman, R.S., Zeuzem, S., \& Team, A.S. (2011). Telaprevir for previously untreated chronic hepatitis $\mathrm{C}$ virus infection. $N$ Engl J Med, 364(25), 2405-2416. doi: 10.1056/ NEJMoa1012912

5. Poordad, F., McCone, J., Jr., Bacon, B.R., Bruno, S., Manns, M.P., Sulkowski, M.S., Jacobson, I.M., Reddy, K.R., Goodman, Z.D., Boparai, N., DiNubile, M.J., Sniukiene, V., Brass, C.A., Albrecht, J.K., Bronowicki, J.P., \& Investigators, S.-. (2011). Boceprevir for untreated chronic HCV genotype 1 infection. $N$ Engl J Med, 364(13), 1195-1206. doi: 10.1056/NEJMoa1010494

6. Pawlotsky, J.M. (2013). Treatment of chronic hepatitis C: current and future. Curr Top Microbiol Immunol, 369, 321-342. doi: 10.1007/978-3642-27340-7 13

7. Welsch, C., Jesudian, A., Zeuzem, S., \& Jacobson, I. (2012). New direct-acting antiviral agents for the treatment of hepatitis $\mathrm{C}$ virus infection and perspectives. Gut, 61 Suppl 1, i3646. doi: 10.1136/gutjnl-2012-302144.

8. Stavar, A., Dumitru, I. M. \& Rugina, S. (2014) Considerations on the daa therapy at the patients having chronic hepatitis from constanta county. Acta Medica Marisiensis. 60(5), 204-206. https:// doi.org/10.2478/amma-2014-0043 